\title{
Lordship and Faith: the English Gentry and the Parish Church in the Middle Ages
}

Review Number: 2135

Publish date: Thursday, 13 July, 2017

Author: Nigel Saul

ISBN: 9780198706199

Date of Publication: 2017

Price: $£ 75.00$

Pages: 384pp.

Publisher: Oxford University Press

Publisher url: https://global.oup.com/academic/product/lordship-and-faith-9780198706199?cc=gb\&lang=en\& Place of Publication: Oxford

Reviewer: Robert Swanson

The medieval English parish was a fiendishly complex organism, whose intricacies become increasingly brain-frazzling as their microscopic analysis advances. Despite all the attention it has received, in many respects the history of the pre-Reformation parish remains in many of its aspects terrifyingly incomplete, and scholars working on it even across small geographical areas often have to work from alarmingly limited and deceptive source bases. In recent years much of the scholarship has concentrated on churchwardens' accounts and reconstruction of the parochial community from the bottom up. However, it is worth recalling that only some 200 sets of churchwardens' accounts have survived from the 9,000 or so parishes in preReformation England; and few of them extend beyond a couple of decades. Statistically, in terms of the whole country, they offer an almost insignificant fragment of the imaginable total which might once have existed. Despite that, they underpin much of the recent work; although the overall picture at the national level can only be an incomplete and debated sketch.

The gentry have usually been strikingly absent from the parochial reconstructions based on such accounts, an absence which contrasts markedly with their prominence in manorial society, their frequent colonisation of ecclesiastical space for memorial purposes, and their engagement with many of the key devotional trends of the later middle ages. Since the 1980s that sense of gentry absence has fed a long-running debate about the nature of the gentry's involvement in the parish (sparked off by an article by Colin Richmond) which has bubbled along in the background of 'parish studies'. This has sought to clarify the extent of their engagement, and how far they did as Richmond suggested by withdrawing from participation in the parochial community and retreating into the private religion of their manorial chapels and oratories. Those questions have perhaps been addressed more by scholars working on seigneurialism than by those who label themselves as 'ecclesiastical historians'; but it is unavoidable for any serious analysis of the functioning of the parish in pre-Reformation England, and potentially for establishing the foundations of the postReformation squirearchy.

With much of the relevant discussion contained in articles or addressing the question as a side-issue in broader analyses, Nigel Saul's volume - which at first sight of its title seems to promise an attempt at resolving the tensions between lordship and faith inherent in gentry status within a parochial context (at 
least, for those who did actually exercise the lordship) - is immediately attractive. Having worked extensively on the gentry in general, often through regionalised case studies, he has repeatedly picked up on their role within the parish and their concern with memoralisation and dynastic display, concerns often reflected through analyses of the surviving material culture in projects ranging from the complete rebuilding of churches to smaller scale and individualised funeral monuments. In this volume those strands are brought together and enhanced in a far more synthetic assessment of 'the English gentry and the parish church' which extends from the Anglo-Saxon period through to the Reformation - although for the most part concentrating (as the sources do) on the period from the early 13th century up to the early 16th. While offering a general overall evaluation, the underlying thrust is subtly directed towards providing Saul's own response to the challenge of 'the Richmond thesis' - a thesis which he ultimately rejects.

The book's goal is certainly ambitious. Within the space of what (for its ambitions) is a relatively short volume - 332 pages of text, reduced to around 300 by allowing for illustrations - it covers a great deal of ground, over both time and space. The spine is provided by a focus on what Saul calls " gentry churches" that is churches either built and furnished by members of the gentry or extensively embellished by them' ( $p$. 4). Such buildings - as spaces and edifices - provide focal points throughout the book, for both the treatment of the parish and the discussion of the gentry's involvement with it; but the overall scope as set out during the introductory chapter one, is potentially much broader. It is succinctly summarised as 'the English medieval gentry class and their interactions with the parish church, taking in such matters as their use of the church and appropriation of space within it, their role as patrons and builders, and their relations with fellow parishioners, whether collaborative or adversarial' (p. 11).

The goal and approach are further fleshed out in that introductory chapter; the book as a whole unpacks the prospectus and transforms it into an argument. Sandwiched between the introductory scene setting of chapter one, on 'The gentry and the parish church', and a final 'Conclusion' in chapter 14, twelve thematic chapters deal with a succession of specific elements, including 'Churching the landscape' (chapter two), 'The gentry and the regulars' (chapter four), and 'Chantries and intercession' (chapter seven), to 'Patterns of burial' (chapter eight), 'Late medieval church building' (chapter ten), 'Lordship and patronage' (chapter 11), and 'Boundaries, structures, and collaboration' (chapter 13). The treatment in chapters two to four is strongly chronological, tracing the initial creation of parishes under the Anglo-Saxons, and the impact of the Norman invasion and the expansion of the new monastic orders (and, in due course, the friars) as factors in the evolution of the parishes in the 12th and 13th centuries (with the discussion of the regulars extending further in time). Thereafter, while there is a chronological underpinning, the treatment is more firmly topical, and more firmly located in the later medieval centuries.

A full summary of these thematic chapters is impossible within the space available here. Suffice to say that the book offers an impressive and richly allusive treatment of its multi-faceted subject, and the scale of the achievement must be firmly acknowledged. This is a major addition to the scholarship on the English parish, and a book which will definitely make its mark. It certainly gives the gentry their due, providing an indispensable introduction and stimulus for further investigation.

As Saul acknowledges, as the first attempt to provide a consolidated overview of the gentry's parochial activity, the book can only be a sketch, and at times perhaps only a tentative one. He admits that his reconstruction 'may be ... in places ... lacking texture and depth' (p. 18). That is indeed true, but it would be churlish here simply to pick the nits and complain that the book's undeniable riches are not rich enough. Nevertheless, it does sometimes generate some unease. The writing is often concise, to the point of creating a sensation that Saul is reluctantly working under constraints; that there is much more which needs to be said - and which he would like to say - but his word limit curtails comment, and forces the book into an uncomfortable strait-jacket. Hints are dropped but not fully followed up, lines of investigation suggested without development.

Whatever the reservations it sometimes arouses, there can be no doubt that this is an important work. Beyond responding to the existing debate about the gentry in the parish, Saul also wishes 'to move the 
agenda forward to attempt an overall interpretation of the changing dynamics ... [of the gentry's relationship with the parish and the parish church] in the medieval period ... [to establish] a new framework ... for the study of the interaction of the gentry with the buildings and institutions of the parish, which will serve as a foundation for further studies to come' (p. 16). It is not clear whether those further studies are works of his own already in progress, but there is here an invitation to reflect on the challenges which he has both accepted and thrown down. There is a risk that such reflections and suggestions for further enhancement will be read as a list of defects and weaknesses, a negative response to the book. A disclaimer is therefore needed: that interpretation emphatically should not be applied here.

Possibly the key point about the overall shape and shaping of the book is that it is specifically part of Saul's overall and evolving oeuvre, moulded by the focus on the gentry which has been characteristic of his work. Its conception is, therefore, framed as an aspect of what might be called 'gentry studies'; but that itself provokes a question: just how distinctive is the 'gentry church', or a 'gentry parish' when compared to other potential categories of parish? How far does the 'gentry church' differ from others? As is sometimes acknowledged, but not always developed, the gentry's involvement in the parish invites not just statement, but comparison and contrast: how does the 'gentry' church/parish compare with the 'noble' equivalent, or a 'mercantile', 'urban', even 'clerical' church or parish? While continuities can be established, the fluidity, elasticity, and imprecision of 'the gentry' as a category also creates problems. Saul offers his own (valuable and useful) definition, limiting them to perhaps fewer than 3,000 landowning families - with the families which actually counted fluctuating over time and space. There are occasional hints that the numbers and qualifications, and so the overall sense of 'gentry' activity, might be extended by adding 'parish' and 'urban' gentry to the total, with their narrower and different horizons. Their existence is acknowledged - more in passing than commentary - but they are not fully integrated into the discussion.

There is also throughout a sense of an inherent but unacknowledged tension: while the book is about the gentry and the parish church, what exactly does that mean? Is the church merely an architectural entity, it and its furnishing simply a facet of material culture which can be analysed in terms of patronage and exploitation; or is 'the parish church' a shorthand for the parish and the parishioners as a social and spiritual unit? The ambiguity is inherent in the initial statement of aims, where 'relations with fellow parishioners, whether collaborative or adversarial' drags a potential Trojan horse into the project. The concealed threat is again suggested with the summative statement of the desired end product, 'a fairly comprehensive picture of the gentry's involvement in the parish and the parish church in the medieval period' (p. 18). Practicality - or word limit - leads to a volume in which the core is constructed around the churches as sites and buildings. While the commentary regularly expands around that core, pointing the analysis in important directions, that expansion is often cut short, leaving a sense that while the discussion has been yanked back towards the core it really wants to be more disparate and diffuse.

The focus on the gentry dictates the book's main concerns, reasonably enough; but the ambivalent duality of its core - gentry and parish, or gentry and parish church? - does becomes problematic. Here the agenda may need some further reshaping: the call for further studies is also a request for 'any other business', and in terms both of 'gentry studies' and 'parish history' there are areas where expansion of the coverage certainly seems appropriate, even necessary. The essential point is definitely not that Saul is unaware of the issues, but that he lacks room to develop them in full, which brings a degree of distortion into the discussion. That appears, for instance, with the lack of comment on chantries and colleges as incubi within the parish. Although both sets of institutions are discussed, in chapters seven (chantries as intercessory institutions) and 12 (the transformation of churches into collegiate institutions to enhance intercession), they are considered essentially as intercessory projects to complement and enhance parochial religion. The fact that, once founded, and particularly when founded as fully independent institutions (even if not actually located in the parochial church), they could also generate long-term dissension and division, is not really considered.

Similar - perhaps more serious - distortion appears in chapter 11, on 'Lordship and patronage'. 'Lordship' here correlates with patronage over parochial benefices, not manorial seigneurialism. That does seem to be ignored, despite obvious overlaps between manorial and parochial communities - although there are 
significant comments on those in the book's final paragraphs (pp. 331-2). The detailed practical consequences of such overlap do sometimes appear in manor court records, reflecting communal concerns about the maintenance of the parish church (or local chapel), and providing (among other things) opportunities for collaboration between lords and tenants to establish a communal chantry.

Patronage, the appointment of a parochial incumbent (usually the rector), was certainly a major consideration in gentry dealings with the church, and in its complexity could probably provide material for a whole book, not just part of a chapter. It allowed gentry patrons to use their advowsons or rights of nominations as a means to shape the careers of relatives and dependents, and to influence the spiritual life of 'their' parishes. It could allow the appointment of men of particular religious leanings; it could certainly be a means of reinforcing authority within the parish via the incumbent (the direct relations between gentry and incumbents - and with other clergy working within the parish - are perhaps another aspect deserving more extended and solid investigation). The exercise of ecclesiastical patronage could also lead to disputes and litigation, as rights of patronage were challenged and usurped. Saul does outline a couple of specific (and lengthy) cases, drawn from cartulary and chronicle evidence. Both stress conflict between gentry patrons and religious houses, but such battles are perhaps unrepresentative of the normal contests over advowsons, certainly after 1300, where rival claimants to patronage (often but not always gentry on one or both sides) and their candidates fought for possession (sometimes repeatedly) in royal and ecclesiastical courts, including Rome. The problems of patronage took many forms, generating rivalries both within a family (particularly when an inheritance was divided, and ecclesiastical patronage also had to be shared out as part of that process), and between different families claiming on grounds of variable speciousness. Legal records and rulings, of both canon and common law, are perhaps surprisingly under-used here, leaving a significant gap in the overall assessment; but it is a gap which seems to pervade the available discussions of patronage. The gap can be noted, but is not raised a point for point-scoring.

The overview is extensive, and as detailed as space allows. There is - as might be expected - particular strength in the discussion of individual extant churches as illustrative case studies. Direct engagement with the Richmond thesis comes relatively late, in chapter 13 ('Boundaries, structures, and collaboration'). Saul argues a strong case against the claims of disinterest and alienation, a case which makes sense. In places, though, it is a problematic argument, in part because of the challenge of moving from individual case studies to a valid generalisation, and the difficulty of finding enough solid evidence to provide the dots which need to be joined up. Gaps can be filled by common sense, and sometimes are: if there was no-one else to provide the funds and leadership required for a major parochial project, then it can be surmised that they were supplied by the gentry, even if not formally and archivally acknowledged. Surmise, though, cannot become assumption; to make such gentry collaboration the default position would distort just as much as claims for gentry withdrawal from parochial engagement.

A couple of areas do seem to be neglected, basically because of the seeming uncertainty about what 'the parish church' means for the book's structure. While the edifice lies at the heart, it is also emblematic of the parish as a territorial and social entity. As Saul regularly points out (and has demonstrated in earlier work), the edifice provided a site for family commemoration and aggrandisement, primarily through its accommodation of chantries. Yet, beyond their creation, these receive little detailed attention in the book. They were, though, potentially as much sources of discord as of prayers. On one hand, as distinct benefices using the term loosely, to incorporate those whose priests were stipendiaries appointed by feoffees, in addition to those whose cantarists enjoyed freehold tenure and episcopal institution - their priests would have divided loyalties within the parish, formally required to proffer obedience to the parochial rector (or his vicar or curate) but financially independent (if beneficed) and so less easily controlled, or perhaps (if stipendiaries) liable to pay more attention to the wishes of their paymasters than the parochial incumbent. On the other, the existence of these separate institutions created new gentry concerns within the context of church and parish. The families - if they actually bothered about their ancestors - would presumably want to supervise their feoffees, and ensure that the endowment was not eroded or embezzled. They would probably be even more directly involved in exercising the patronage of the true benefices. 
The focus on gentry activity within the parish church as the parish's core spiritual site also tends to marginalise - or overshadow almost to the point of exclusion - the potential for gentry influence on subsidiary chapels, as more localised nodal points within the parish. There is indeed engagement with the issues raised by the proliferation of domestic chapels, unavoidable as a key factor in 'Richmond thesis' of gentry alienation. Less attention is paid to the potential influence of gentry in the encouragement of local chapels in subsidiary settlements (some doubtless also having the status of manor chapels), where the gentry could perhaps create their own quasi-parochial arrangements to challenge (or evade) ecclesial dominance by other families. Sometimes this extended to active support for attempts to gain full parochial status for their protégé chapels, support which could then produce its own conflicts. Such chapels provided precisely the opportunity and context for familial propaganda which Saul sees in parish churches - perhaps with greater freedom than would be enjoyed at those churches, because in the chapels there would be no rectorial interest to bar (or shape) intervention in the remodelling of the chancel.

Clearly, there remains more to be said about the gentry and their relationship both with the parish as a whole, and with individual parish churches; possibly Saul plans to say some of it in further work. For now, as an incentive for others to investigate further, he has delivered a book which is fundamentally trail-blazing, decidedly stimulating, offers much, and is definitely welcome. It reflects a truly ambitious and challenging project, one which perhaps only Nigel Saul could tackle over such a broad canvas, and with such deft expertise. There are points to quibble with, but they do not diminish the reality of the book's significance for both 'gentry studies' and 'parish studies'. Saul not only provides a powerful and nuanced synthesis, he throws down a challenge to take things further, to develop and refine his analysis of the gentry's relations with their parishes and parish churches, and to integrate the 'gentry church' and 'gentry parish' - however eventually configured - into the overall understanding of the complexity of parochial organisation and history in late medieval England. That is certainly a gage which others should take up.

Source URL:https://reviews.history.ac.uk/review/2135

\section{Links}

[1] https://reviews.history.ac.uk/item/264444 